\title{
イスラム僧院建築とスーフィズムの大奥化に関する考察 \\ ベクタシ教団の僧院建築の実測調査を基礎資料として \\ RESEARCH ABOUT DEVELOPMENT OF DERVISH LODGE THAT RELATES WITH POPULARIZATION OF SUFISM \\ The survey of Bektash dervish lodges
}

\author{
山本達也* \\ Tatsuya YAMAMOTO
}

\begin{abstract}
This paper researches about development of dervish lodge that relates with popularization of Sufism. Various bektash dervish lodges in Turkiye were analysed in this research. Popularization of Sufism had two steps. First, Sufism joined men came to the stage, constructing tombs, meeting and pilgrimage rooms which had axis and Islamic proportion were built. Second step was patterned training (style of whirling dance). Beside to whirling dance room, library, Turkish bath and madrasa were constructed. In these buildings Islamic proportion and axis couldn't seem except the axis through Mecca.
\end{abstract}

Keywords : dervish lodge, Sufism, Bektash, whirling dance, axis, proportion イスラム僧院，スーフィズム，ベクタシ，旋回舞踏，軸線，比例

\section{1.はじめに}

スーフィズム (イスラム神秘主義) の大衆化とともに， 教団も修行僧のみの場であったものが，一般大衆のもの となる。教団の組織形態の変革および修行形態の確立に ともない，僧院（テッケ）の存在理由そのものが変移し ていく。その変移をたどり，スルタン等の為政者による ものではない，一般大衆の中世トルコ・イスラム建築に ついて考察することを本論文の研究目的とする。

イスラム世界の各地で高名なスーフィを中心に数々な 教団が作られたが1)，ふたつの理由から，ベクタシ教団 の僧院建築を中心に論ずることにする。第一の理由は, アナトリアの地で結成され，オスマン帝国の親衛隊(イ エニチェリ) と深い関係を持ち，オスマン帝国の版図拡 大に大きな功績を残し，大衆の支持を得たこと。第二の 理由は, トルコ国内に遺構があり, 教団拡大期の資料が 現存するからである2。これらの資料から，ベクタシ教 団はその性格を歷史的に 3 つの時期に分けれる。

(1) 教団成立期（13世紀） 教祖ハジ・ベクタシを中心 に，彼が行なった修行方法を繰り返すことにより，神秘 体験を得ようとした時期。

(2) 聖者崇拝期 $(14,15$ 世紀) 教祖ハジ・ベクタシの 死後, その徳にあやかろうと集まって来た在俗ス一 フィーを教団に取り入れた時期。
(3) 修行道場期（16 19 世紀）修行形態が確立され, 一般の人でも簡単に参加できるようになり，僧院そのも のが共同体の象徵となった時期。

この 3 つの時期に応ずるべく, 新たな僧院の建設, 増 改築が行なわれた。それぞれの建設の様子を, 実測調查 を行なったトルコ国内のベクタシ教団の僧院に関して論 ずる。また資料を補足する意味合いから，他教団の僧院 建築，特にメヴラナ教団のものを参考としだ!。

\section{2. 教団成立期}

ベクタシ教団は，ハジ・ベクタシにより 1270 年, ア ナトリアの小都市ネブシェヒールで結成される。彼の死 後 (1296 年), 生前修行の場として使用していた独居房 が, 教団員の修業の場とされる。また，1298 年には霊 廟が建設される4)。

現在のハジ・ベクタシ霊廟は, ハジ・ベクタシの棺を 中心に彼の子孫等の棺も配され, 建物の一部には旋回舞 踏をするための祭礼場 (七マ八ネ) さえ設けられている。 この霊廟は数度の増改築を経て現在の姿となった ${ }^{55}$ 。正 面入口部分は砂岩の切出し石, 後方の祭礼場は乱石積み であるが，1298 年に建設された本来の霊廟は，大理石 の切出し石により建設されている。さらに, 祭礼場の部 分も大理石の切出し石だが，その大きさが霊廟部分のも 
のに比べて大きく, 霊廟との 連結部分では鉄の楔が石の中 ではなく, 壁に露出する形で 埋め込められている等, 後世 の増築であると考えられる (図一1，2)。八ジ・ベクタ シの棺のある, 本来の霊廟の 入口上部の装飾も, 鐘乳石状 のものであるが, オスマン期 のもののように洗練されたも のではなく, パターン化され る以前の, セルジューク期の

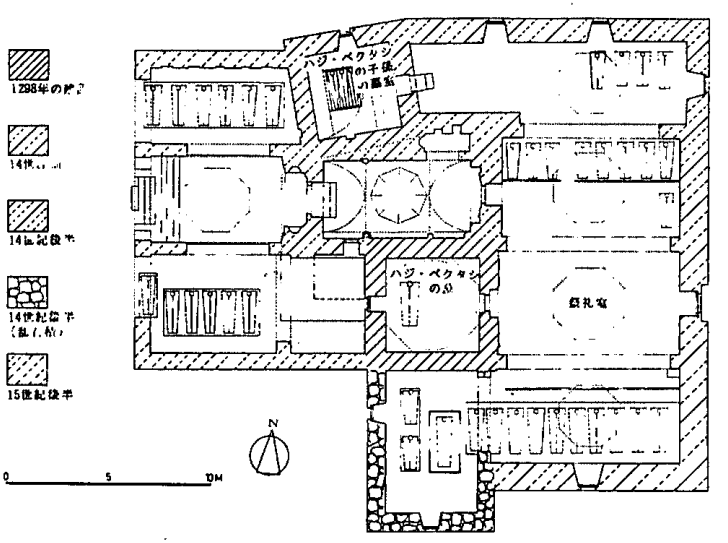

図一1 ハジ・ベクタシ霊廟 平面図

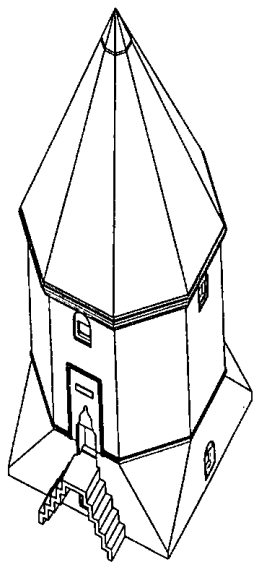

図一4 ハジ・ベクタシ霊廟 復元 形式に属するものである。さ らにその断面を詳しく調べて みると, 高さ $1.20 \mathrm{~m}-3.10$ $\mathrm{m}$ にかけて隅部の切出し石 の一部が傾いた形で積まれて おり，そこに床があったもの と考えられる(図一-3)。初め は墓室と玄室が上下に重なる 形で建設されたが, 時代とと もにハジ・ベクタシの棺の存

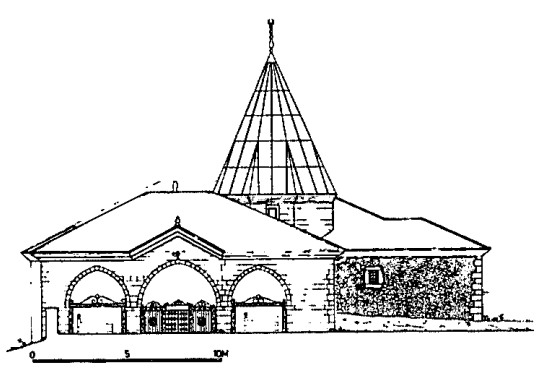

図一2 ハジ・ベクタシ篮廟 立面図

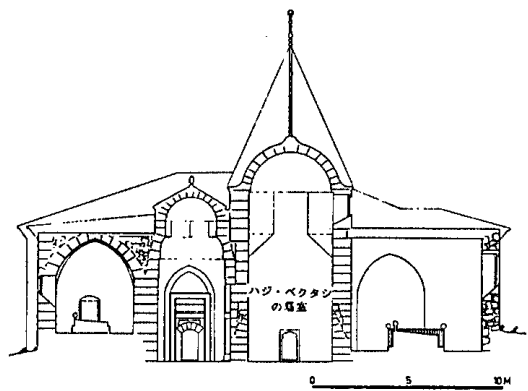

図一3 ハジ・ベクタシ霊廟 断面図 在を強調すべく，玄室の床が取り除かれ，垂直性を強調 する空間に改められたと考えられる。つまり, 高さ $3 \mathrm{~m}$ 程度のヴォールト床 (天井) であった墓室が, 改修によ りドーム天井に改められた。また， $5.32 \mathrm{~m} \sim 6.68 \mathrm{~m}$ の 高さで正方形平面を正八角形平面に移行させているター キッシュ・トライアングルがある。このような構造的特 長から,さらに 13 世紀にアナトリアの各地でさかんに 建設されたキュンベットと呼ばれた墓標を参照しつ つ), 復元してみると, 図一4のようになる。

セイット・バッタル・ガジ僧院 (ベクタシ教団) の霊 廟でも同じようなことが言える。この建物では最初から 霊廟がモスクとの複合施設として 1208 年に建設され, 墓室と玄室は分けられることなく, 初めからひとつの空 間として計画された7)。イスラム建築で重視された黄金 比による比例関係は断面で使われている。一辺が 5.05 $\mathrm{m}$ でその径が $10.85 \mathrm{~m}$ の正八角形平面で, 高さ $15.83 \mathrm{~m}$ のドーム天井の墓室である。切出し石によって壁は $7.60 \mathrm{~m}$ の高さまで垂直に積まれ，そこでス.クインチに より，10.85 m の高さで正十六角形にその平面を変え, その位置よりドームが立ち上がる。つまり，スクインチ の架った部分とそれ以外の部分の比は, $1: \phi^{2}(\doteqdot 3.25$ $\mathrm{m}: 7.60 \mathrm{~m})$ になる。ドームの真下，床より $3.40 \mathrm{~m} の$ 高さに,この霊廟の視覚的中心であるエメラルド・グ リーンの球体が吊られる。この球体は，霊廟室内を高さ で $1: \phi^{3}(\doteqdot 3.40 \mathrm{~m}: 15.80 \mathrm{~m})$ に分割する。

教団成立期の僧院建築としては, ベクタシ教団のこの

$2 つ$ 霊廟建築の他には，トルコ国内ではメヴラナ教団 の総本山であるコンヤのメヴラナ僧院の霊廟が現存する 程度である。

\section{3. 聖者崇拝期}

聖者の遺徳を慕って在俗スーフィたちが集まってく る。教団は彼らの要望に応えるべく, 教団成立期の建物, 特に霊廟のまわりに様々な施設を建設する。まず説教の ための礼拝堂, 会合を行なうための集会室が, さらに個 人の修行の場として僧房が建設される。修行僧は空ひと つない僧房の個室に籠り，精神の緊張を高めることに努 めた。暗黒の僧房で見た様々な像 (イマージュ) がその 修行僧の精神状態を示し, 高僧の指導により, より上位 の悟りを得る手掛りとなった。ハジ・ベクタシ僧院では, 木組みのドームの架った集会室と細長いL字形の廊下で 結ばれた小室がその修行に使用された。セイット・バッ タル・ガジでは, 隣接のビザンス教会の基礎を利用し, ウンミュハン・ハートゥン霊廟（13世紀）に僧房が増 築された ${ }^{8)}$ 。アマスヤのヤクプト・パシァ僧院（メヴラ ナ教団, 1413 年) では, 狭小の暗室 (一辺が $1.8 \mathrm{~m}$ の 立方体）が並べられている9)。

礼拝室, 集会室, 僧房に続き, 巡礼をする修行僧たち のための宿泊施設, 㴻房, 食堂等が建設される。ハジ・ ベクタシ僧院では中庭を挟み, 北側に集会室, 僧房が, 南側に来訪者たちの施設が建設された。これらの施設は， 材料の不揃い, 各種の構法の採用等から, 一度に建設さ 


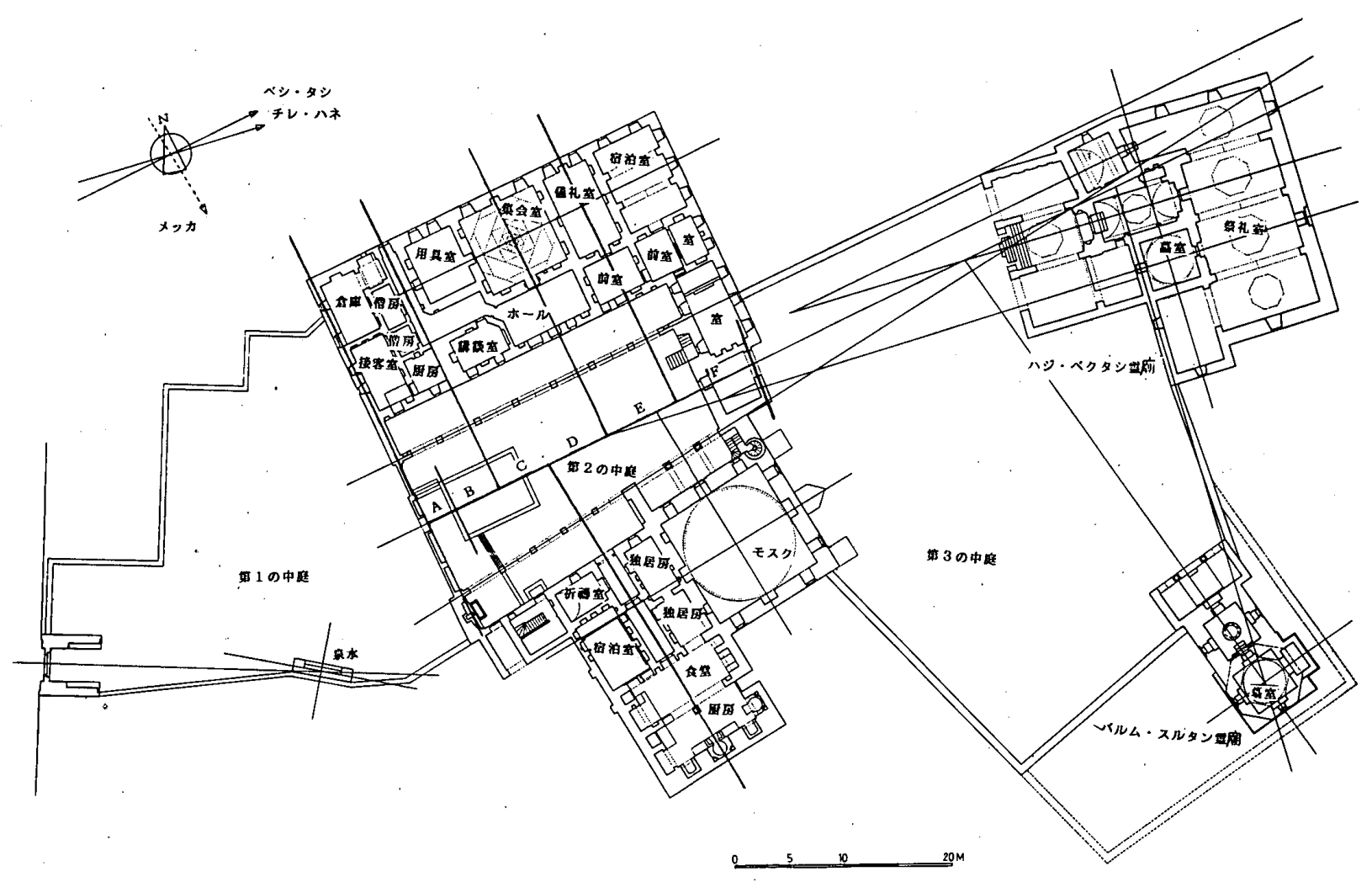

図一5 ハジ・ベクタシ僧院 平面・分析図

れたものではないと考えられる。それにもかかわらず， パースペクティブ, 軸線を意識したプランから, 同時期 に前後して建設されたものと考えられる ${ }^{10)}$ 。分析図 (図 一5）で示した通り，中庭を貫く軸線とそれを分割する いくつかの軸により，諸施設の配置が規定されている。 中庭を貫く軸は，ハジ・ベクタシが修行のため籠ったべ シ・タシの方角を示しつつ, 両端の 2.つの門の中心を 通っている。そして中央の中庭部分では, $\mathrm{A}$ 一 F の部分 を, $3: 4: 5: 6: 7: 8$ の比の長さに分割される。北側 の棟の連続アーチからの距離は $6.18 \mathrm{~m}$ で, 回廊の内法 が $3.82 \mathrm{~m}$ であるから，之の比率は $\phi: 1$ である。旡房 のかまよ゙から発せられた軸も同じように $\phi: 1(\fallingdotseq 6.18$ $\mathrm{m}: 3.82 \mathrm{~m})$ に分割されている。そして建物の内部に入 り, 通路部分は $5: 6$ に分割され, 厨房, 食堂が $7.50 \mathrm{~m}$ 四方の部屋となる。この大きさは集会室と同じである。 中庭を貫く軸線からの距離も同じ（連続アーチまで $6.18 \mathrm{~m})$ であり, 両者とも儀礼の空間として僧院の中 で同じ比重をしめていたと言える。また, 礼拝室のミヒ ラブから発せられた軸（キブラ軸）は $\mathrm{E} の$ 部分を $\phi^{2}: 1$ $(\fallingdotseq 5.06 \mathrm{~m}: 1.94 \mathrm{~m})$ に分割する ${ }^{11)}$ 。さらに, ベクタシ 教団の修行場のひとつであるチレ・ハネの方角を示す。 ハジ・ベクタシの墓室から発せられた軸は, 中庭を貫通 する軸と集会室から発せられた軸との交点で交わる。

\section{4. 修行道場期}

15 世紀後半より，教団はさらに大衆に開かれたもの
になる。スーフィを自認しない一般の人々も教団の活動 に加わるようになる。僧院によっては, 鉎冶屋, 皮革, 染物，屠殺等の職人たちの同業者たちが集まり，僧院の 経営を助けるようになる ${ }^{12)}$ 。さらには, 僧院そのものが 同業団のものになったものもあり，親方（ウスタ）が僧 院長となり, 僧院内に彼の住宅が設けられる。僧院に従 属する修行僧の多くは, 職人 (カルファ), 徒弟 (チュ ラク）であった ${ }^{13)}$ 。そして，このような僧院は同業団の 構成員同士の相互扶助団体としても機能した。一定額の 分担金を徴収し，それによって必要な時に構成員に貸付

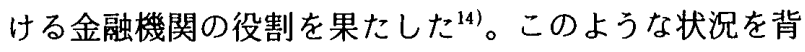
景に，僧院は同業団を中心とした共同体の象徴となって いった。

一般大衆の参加は,その修行形態を大きく変える。スー フィのように修行を専業としているわけではないので， 修行の簡略化, 形式化が必要であった。つまり, 誰もが 生業に携わりながらでき，それでいて神秘的な感覚に酔 うことのできる修行方法が考え出される必要があった。 16 世紀には，唱名（ズグル）と旋回舞踏（セマ）が修 行として確立してくる。

唱名と旋回舞踏が修行として確立することにより，そ. れらの修行の場として新しい形の僧房, 祭礼室(セマハ ネ) が建設される。僧房は読書を目的とすることから ${ }^{15)}$, 聖者崇拝期のものとは異なり, 明るく, 暖炉等の設備の ある個室となる。この僧房は, 図書室や神学校のように 共同体を象徴する施設等の併設により, 修行よりも教育 
という意味合いを強くしていく。

祭礼室が新たに僧院の中心的施設となる。舞踏の性格 上，聖者崇拝期にみられた軸線を重視した配置は，ミヒ ラブの存在によりかろうじてキブラ軸が認識される程度 にとどまり，それに代わって中心性の強いプランが選択 されるようになる。この時期にオスマン帝国がヨーロッ

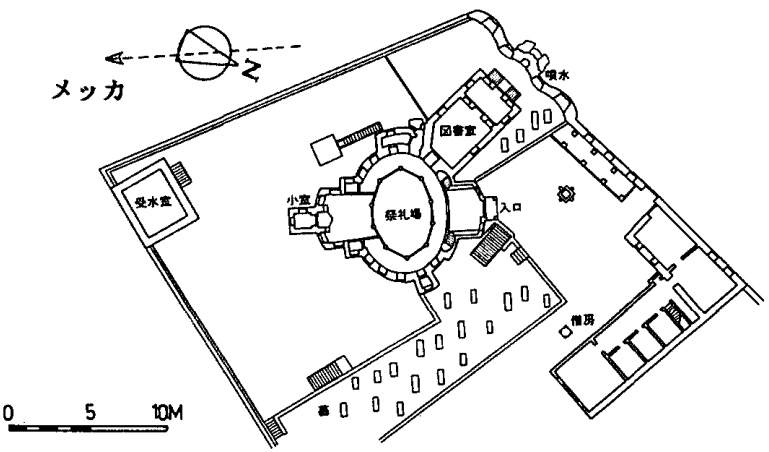

図一 キュチュック・エフェンディ僧院 平面図
パ世界，特にフランスと友好関係を結んだこともあり， バロック，ロココ建築の影響を受けたことも，この変化 に拍車をかけた ${ }^{16)}$ 。バロック建築の影響を強く受けた僧 院建築としては，イスタンブール市内のキュチュック・ エフェンディ僧院（ベクタシ教団）をあげることができ る(図一6)。この僧院の祭礼室は楕円形であり, 外壁も 大きく湾曲する。図書室は祭礼室に付属する平面になっ ているが，別に外からも訪問することができるように なっている。これは旋回舞踏中の教団員の賏想状態を壊 さないためである。僧房の一部は，代々皮革職人の親方 である僧院長の住宅として使われていた。

旋回舞踏は, 聖者崇拝期においては聖者に捧げる踊り であった。ハジ・ベクタシ霊廟内の祭礼室は聖者崇拝期 のものであり，ハジ・ベクタシの墓室への前室的意味合 いを持っている。そのため, 修行道場期の例に比べて空 間の集中性はあまり考慮されておらず，床に円形の絨毯
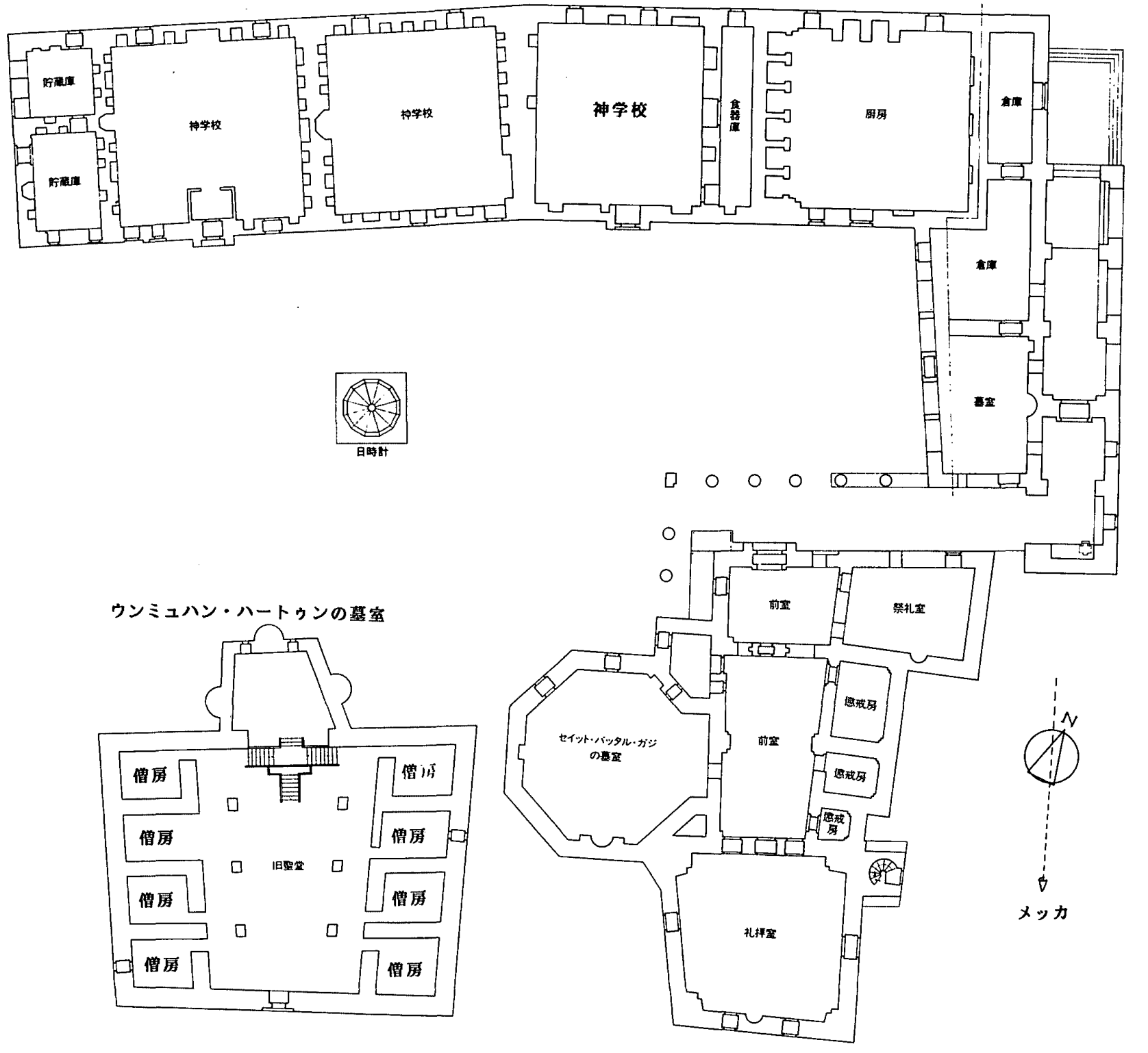

$20 \mathrm{M}$

図-7 セイット・バッタル・ガジ僧院 平面図 
を敷く程度にとどまっている。当時の綫毯は現存せず， 初めから円形であったのかどうかはわからない。

旋回舞踏が, 聖者に捧げるものから修行としての要素 を強めるに従い，踊りの中心を必要とするようになる。 15 世紀後半にはベクタシ教団の旋回舞踏もメヴラナ教 団の影響を受け17)，次のようになる。修行僧は祭礼場に ひとつの中心軸（通常, 僧院長がその役目をする）を設 定し，そのまわりを自分自身も左足を軸に左回りに回転 しながら，その円周上を左回りに回る。修行僧は旋回す ることによって心理的に高揚し, 忘我の境地に達する。 このとき，祭礼場を恒星と惑星からなるひとつの宇宙に 見立てようとしている。また, イスラムの 5 行「信仰(シャ ハーダ), 礼拝 (サラート), 断食 (サラム), 喜捨 (ザカー 卜), 巡礼 (ハッジ)」のひとつである巡礼の最終行為で ある周巡（タワーフ）をも意味している ${ }^{18) 。 こ の よ う に ~}$ 舞踏が意味づけられた上に, 音楽等の助けにより安易に 非日常的経験ができることにより，誰にも受け入れやす いものとなった。

セイット・バッタル・ガジ僧院の中庭に日時計がある が $(\text { 図一7 })^{19)}$, この時計の存在も, 旋回舞踏の発生とは 無関係ではない。祭礼場を恒星と惑星から成る小宇宙に 見立てた場合，この日時計は恒星であり，そのまわりを 回る修行僧は惑星となる。ただし，修行が形式化するに 従い，祭礼場は気候の影響を受けにくい室内へと移って い。

このような旋回舞踏に応えるべく建設された祭礼場を 持つ僧院が，イスタンブール市内のメルディベンキョイ 僧院 (ベクタシ教団) である。初めから修行道場として 建設された建物であり，聖者を祀る霊廟はない。祭礼室 の他には, 神学校, 説話室, トルコ風呂, そして僧院長 の住宅を含んだ僧房がある（図一-8）。トルコ風呂の存在 は, 礼拝前の沐浴ばかりでなく, 旋回舞踏を行なった後, 修行衣を脱ぎ，汗を流すためである。このことは旋回舞

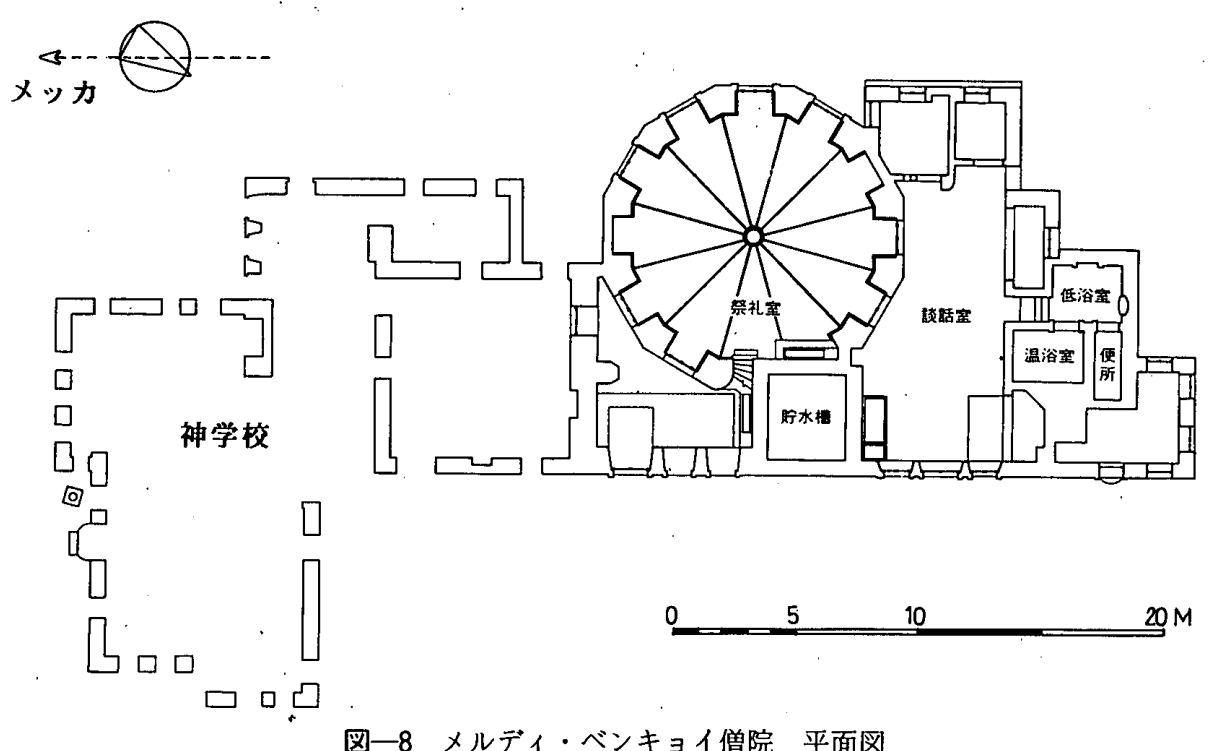

図一8メルディ・ベンキョイ僧院 平面図

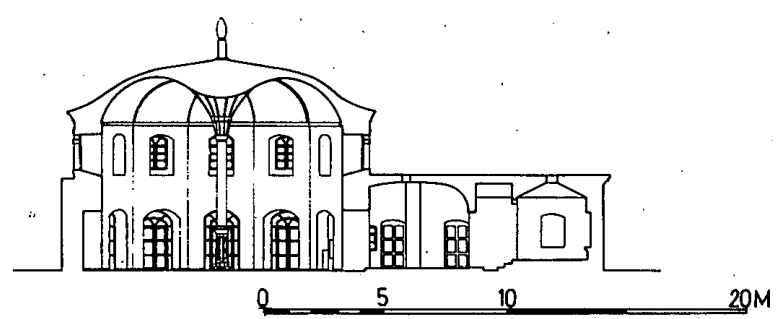

図一9 メルディ・ベンキョイ僧院 断面図

踏が宗教的行為の他に，娛楽（スポーツ）的意味を持っ ていたと考えられる。市内のトルコ風呂が一般大衆の娛 楽の場であり, 共同体の象徵であったように, この僧院 がこの地区の共同体の生活の一部になっていたことを示 $\Phi^{20)}$ 。

メルディベンキョイ僧院の祭礼室は正十二角形平面 で，その中央に円柱がある。その円柱はイスラムの象徽 のシンボリズムに則った形で装飾が施されている21)。

18 世紀後半, 19 世紀には, メヴレビ派の祭礼場 (メ ヴレビハネ）が各地に建設されるが22)，メヴレビ派の修 行方法のひとつである旋回舞踏の形式に合わせ ${ }^{23)}$, 集中 式平面を採用する24)。しかし，メルディベンキョイ僧院 のように，その天井がドーム状になることはない。集中 式平面にもかかわらず，それが断面には反映されない。 その理由としては, 天井の高さが増し, 天井の形状その ものがあまり意識されなくなったこと。音楽を演奏した 際, ドーム天井では音が籠ってしまい, 舞踏がしにくい こと。さらに，木天井に様々な幾何学文樣, 植物文様を 刻むことにより, モスクのドームとは別の象徵性を得る ことができたからだと考えられる。

このように天井の祭礼室がトルコ・イスラム僧院建築 のアーキタイプとなっていく中で，メルディベンキョ・イ 僧院だけが特異な展開をした。断面（図一9）を見てみ ると，その天井はドームであるが，ドーナツ状のドーム 天井であり，モスクのドームのように音が籠ることはな い。また，高さが $8.20 \mathrm{~m} も$ あり，旋回舞踏を行なってい る人以外はその天井を意識す ることはない。さらに, 中央 の円柱が象徴的であるため, そのシンボリズムと調和をと る意味合いからも，このよう な形態となる必要があったと 考えられる。

次にベクタシ教団の他の僧 院で考察したように、メル ディベンキョイ僧院において。 も，その比例関係を考えてみ る。祭礼室は一辺が $3.30 \mathrm{~m}$ でその半径が $6.30 \mathrm{~m}$ の正十 
二角形平面で, ドームの最上部まで $8.20 \mathrm{~m}$, 下端まで $6.05 \mathrm{~m}$ である。ということは, 祭礼室の高さと平面の 関係は, $6.30 \mathrm{~m}: 8.20 \mathrm{~m}=1: 1.30,6.30 \mathrm{~m}: 6.05 \mathrm{~m}=$ $1.04: 1$ である。上空の大きさは $1.75 \mathrm{~m}$ であり, 床よ り下端まで $3.85 \mathrm{~m}$, 上端まで $5.60 \mathrm{~m}$ である。これらを 壁の高さ,つまりドームの下端までの, $6.05 \mathrm{~m} て ゙$ 比を 出してみると, $1.75 \mathrm{~m}: 6.05 \mathrm{~m}=1: 3.45,3.85 \mathrm{~m}:$ $6.05 \mathrm{~m}=1: 1.57,5.60 \mathrm{~m}: 6.05 \mathrm{~m}=1: 1.07$ となる。 扉と空が同じ形でデザインされている開口部の高さは $2.35 \mathrm{~m}$ である。これを壁の高さと比べてみると, 2.35 $\mathrm{m}: 6.05 \mathrm{~m}=1: 2.57$ となる。これらの数值は, 教団成 立期および聖者崇拝期のベクタシ教団の僧院のように, фを使った比例関係がないことを示す。修行道場期のべ クタシ教団の他の遺構を詳しく調べてみる必要がある が，集中式平面の採用，イスラムの象徵のシンボリズム の建築化により, 修行道場期においては, 比例関係が他 の時期に比べ，あまり重視されなくなっていったと考え られる。

\section{5.おわりに}

スーフィズムの大衆化の過程から, 教団の性格も 3つ の時期に分けられる。僧院建築もそれぞれの時期に対応 すべく発展する。僧院の本格的な建設そのものは, 教団 への在俗スーフィたちの参加により始まる。教団成立期 の墓標は霊廟になり, 聖者崇拝の象徵なる霊廟を中心之 して礼择室, 集会室, 巡礼者のための宿泊施設, 旡房, 食堂等が建設された。

修業形態の確立とともに，僧院はスーフィたちのもの から一般大衆のものになる。安易に神秘的な感覚に酔う ことのできる修行方法 (唱名, 旋回舞踏) が考え出され ることにより，僧院は修行道場化する。そのため 16 世 紀以降の僧院では霊廟は建設されなくなり，僧院の中心 的施設は，旋回舞踏の場である祭礼室に移る。このよう に修行道場期にその性格を変えた僧院は, 共同体の象徵 となるべく，浴場，図書室，神学校を併設するようにな る。平面もメルディベンキョイ僧院等のように集中式平 面となり, 軸線と比例関係は, 聖者崇拝期に比べ，あま り重視されなくなる。つまり，僧院の大衆化とともに， 僧院そのものも大衆によりわかりやすい平面, 形態に変 化していった。

ケマル・アタテュルクの改革により, 現在のトルコ共 和国内では，スーフィズムの信仰は禁止されている。さ らに，トルコ人による研究は極端に制限されている ${ }^{25)}$ このような状況の中で，ハジ・ベクタシ僧院（1983年 8 月, 1988 年 4 月, 1991 年 4 月), セイット・バッタル・ ガジ僧院 (1983 年 8 月, 1991 年 3 月), メルディベンキョ 亿僧院（1983 年 8 月，1989 年 6 月）で行なった実測調 查への許可, さらに, ハジ・ベクタシ僧院博物館図書室
蔵およびメルディベンキョイ僧院蔵の文献の閲覧許可を 出していただいたトルコ政府およびトルコ政府宗教建築 保存団体アンカラ本部に深く感謝します。

\section{注}

1) アナトリア以外で結成され，アナトリアにも伝播された 教団：Kazerun (1034), Kadir (1167), Rifa (1182), Sadi (1300), Nakşibendi (1390), Halvet (1397), Zeyni (1434) アナトリア以外で結成され，アナトリ アには伝播されなかった教団：Yesev（1167), Medyen (1194), Kübrev (1221), Suhreverd (1254), Çeşti (1255), Şazel (1258), Bedev (1276), Desuk (1295) アナトリ アで結成された教団：Bektaş（1270)，Mevlevi (1273)， Bayram (1430)

2)「ハジ・ベクタシ僧院博物館図書室蔵古文献集」No. 01 (15世紀), No.02 (16,17,18 世紀), No.03 (15, 16 世紀), No.04 (16,17 世紀)，No.05（18，19 世紀）， No. 07 (19 世紀), No. 08 (18, 19 世紀), No.09 (17, 18 , 19 世紀)，No. 10 (16, 17，18 世紀), No. $11(17,18$ 世紀), No.12 (14, 15, 16, 19 世紀), No.13 (17, 18 世 紀), No.14 (17, 18 世紀), No.15 (17 世紀)。「メルディ ベンキョイ僧院蔵古文献集」No. 01 (16, 17, 18, 19 世紀), No. $02(17,18$ 世紀)。

3) Celal Esat: Mevlevilik ve İstanbul Mevlevilik, İstanbul, 1912. Mehmet Ziya : Yeni kapı Mevlevihanesi, I stanbul, 1913. Asaf Halet Çelebi : Mevlana, İstanbul, 1939. Can Karamentli : Galata Mevlevihanesi, Türkiye Turing ve Otomobil Kurumu, 1978

4）八ジ・ベクタシ僧院博物館図書室蔵古文献集 No. 02-06

5）山本達也：ハジ・ベクタシ僧院調查報告, Turkiye Vakıflar Genel Müdürlüğu Raporları, p.34, Ankara, 1992

6) Orhan Cezmi Tuncer: Anadolu Kumbetleri, Vol.1, p. 177, pp. 336 339, Ankara, 1986

7) Tokgöz Demir : Seyit Battal Gazi Kulliyesi, Eskişehir Anma Gunleri Dergisi, Vol.2, p.5, 1978. Godfrey Goodwin: A History of Ottoman Architecture, p. 182, Thames and Hudson, London, 1971

8) Erol Altınsapan : Seyyit Battal Gazi Külliyesinde Yeralan Ümmühan Hatun Türbesi, I. Uluslararası Seyyit Battal Gazi Semineri Bildirileri, pp. 47 58, Eskişehir, 1990

9) Metin Sözen : Türk Mimarisinin Gelişimi ve Mimar Sinan, p.113, Tưrkiye İş Bankası Kültür Yayını, I stanbul, 1975

10）山本達也：前掲報告書, p. 64

11）ベクタシ教団の信者は, 通常モスクで祈霹を行なうこと はない。そのため, キブラ軸の重要度も, 他のイスラム 建築に比べ，2次的なものになっている。

12) Evliya Çelebi : Seyahatname, Vol.2 pp. 23, 141, 149, 173, 175, 267, İstanbul, 1896

13）トカット・ギョク・メドレッセ博物館図書室蔵古文献集 No. 1202-F 105, 「トカット・メブレビ八ネに関する記録」 によると, 18 世紀には染物業者によって僧院は管理され ていた。 
14) Ahmet Refik : İstanbul Hayat (1495-1882), Vol. 3 p. 92, Enderun Kitabevi, İstanbul, 1988

15）修行としては，教団員は僧房で教団特有の㫛文を絽り返 し唱えた。読書としてはコーランの他に，教祖等高僧に まつわる伝記，彼らの作った伝記等を読んだ。

16) Ayda Arel : 18. yy. İstanbul Mimarisinde Batılılaşma Surreci, pp.11, 53, 105, İstanbul Teknik Üniversitesi, 1975

17) Celalettin Ulusoy : Hacı Bektaş Veli ve Alevi-Bektaşı Yolu, pp. 31, 211, Hacibektaş, 1986. ベクタシ教団の 教祖ハジ・ベクタシとメヴラナ教団の教祖ルーミーは, アナトリアの宗教についてコンヤにて論議し合っている。 そして, 修行方法についてお互いに強い影響を与え合っ ている。

18）ベクタシ教団においては，八ジ・ベクタシが修行したベ シ・タシを訪対た後, ハジ・ベクタシ霊廟を参拝した教 団員をハッジと呼んでいる。

19) Tokgöz Demir : 前揭書,p. 5, 現在, 日時計の上にシャドゥ ルバン（手足を清める所）がある。

20）メルディベンキョイ僧院蔵古文献集, No. 01-12, 01-13

21）芝浦工業大学建築工学科三宅研究室：スーフィの建築 (IV メルディベンキョイ僧院), 新建築 1985 年 1 月号, p. 304,1985 年

22）ベクタシ教団は，18 世紀後半親衛隊（イエニチェリ）の 衰退とともにその勢力を弱めていく。さらに，19 世紀初 めマフマット II 世により断圧され, それ以降, 僧院の建 設はない。

23）注 17）で述べたように, ベクタシ教団の旋回舞踏に類似 している。詳細は,「Metin And：Mevlana Celaleddin Rumi and the Whirling Dervishes, Dost Yayınlar, I stanbul, 1983」を参照

24）イスタンブール・ガラタ・メヴレビハネ (正八角形), 卜 カット・メヴレビ八ネ (正八角形)，ブルサ・メヴレビ八 ネ（正十六角形），キュタヒア・メヴレビ八ネ（正十六角 形) 等。

25）上述したものの他，僧院一般を取扱った研究書としては, Mustafa Kara : Tekkeler ve Zaviyeler, İstanbul, 1980. があるだけである。また，トルコ政府宗教建築保存団体 (Vakıflar) アンカラ本部図書室に，コンヤ・メヴラナ 僧院，カスンパシャ・メヴレビハネ，イエニカプ・メヴ ラナハネ,コジァ・ムスタファ・パシァ僧院等の調查報 告書がある。

(1992 年 2 月 10 日原稿受理, 1992 年 11 月 19 日採用決定) 